GRASAS Y ACEITES 65 (1)

January-March 2014, e007

ISSN-L: 0017-3495

doi: http://dx.doi.org/10.3989/gya.062813

\title{
Functional ingredients and cardiovascular protective effect of pumpkin seed oils
}

\author{
S.Y. Al-Okbi ${ }^{1, \bigotimes}$, D.A. Mohamed ${ }^{1}$, E. Kandil'², E.K. Ahmed ${ }^{2}$ and S.E. Mohammed ${ }^{1}$ \\ ${ }^{1}$ Food Sciences and Nutrition Department, National Research Centre, Dokki, Cairo, Egypt \\ ${ }^{2}$ Biochemistry Department Faculty of Science, Ain Shams University, Cairo, Egypt \\ Corresponding author: S_Y_alokbi@hotmail.com
}

Submitted: 17 June 2013; Accepted: 24 September 2013; Published on line: 13/02/2014

SUMMARY: The objective of the present study was to evaluate the cardiovascular protective effect of Egyptian and European pumpkin seed oil (PSO) in hypercholesterolemic rats. Tocopherols, fatty acids (FAs) and unsaponifiable matter (UNSAP) were assessed in both oils. The results showed that $\alpha$-tocopherol was 108 and 273, $\gamma$-tocopherol was 3.95 and 0 and $\delta$-tocopherol was 0 and $1.58 \mathrm{mg} \cdot 100 \mathrm{~g}^{-1}$ oil of the Egyptian and European, respectively. GLC analysis of FAs revealed the presence of linoleic acid as the major fatty acid in both oils. Feeding a hypercholesterolemic diet produced a significant increase in plasma total cholesterol (T-Ch), triglycerides (TGs), low density lipoprotein cholesterol, T-Ch/HDL-Ch, TGs/HDL-Ch and malondialdehyde and a significant reduction in high density lipoprotein cholesterol (HDL-Ch), vitamin E, and adiponectin. Rats fed on hypercholesterolemic diet with either oil showed a significant improvement in all biochemical parameters.

KEYWORDS: Adiponectin; European and Egyptian PSO; Hypercholesterolemia; Lipid profile; Oxidative stress; Rats

RESUMEN: Ingredientes funcionales y efecto protector cardiovascular de aceites de semillas de calabaza. El objetivo fue evaluar el efecto protector cardiovascular de aceites de semilla de calabaza (PSO) de variedades egipcia y europea en ratas con hipercolesterolemia. Se evaluó tocoferoles, ácidos grasos (FAs) y materia insaponificable (UNSAP) en ambos aceites. Los resultados mostraron valores de $\alpha$-tocoferol de 108 y $273, \gamma$-tocoferol 3,95 y 0 y $\delta$-tocoferol de 0 y $1,58 \mathrm{mg} \cdot 100 \mathrm{~g}^{-1}$ en las variedades egipcia y europea, respectivamente. El análisis por GLC de los ácidos grasos (FAS) mostró al linoleico como mayoritario en ambos aceites. La alimentación con una dieta hipercolesterolémica produjo en plasma un aumento significativo de colesterol total (T-Ch), triglicéridos (TG), colesterol en lipoproteínas de baja densidad, T-Ch/HDL-Ch, TGs/HDL- ch y malondialdehído y una reducción significativa en el colesterol de lipoproteínas de alta densidad (HDL-cH), vitamina E, y adiponectina. Las ratas alimentadas con una dieta hipercolesterolémica y con ambos aceites, mostraron mejoras significativas en todos los parámetros bioquímicos.

PALABRAS CLAVE: Adiponectina; Estrés oxidativo; Hipercolesterolemia; Perfil lipídico; PSO europeos y egipcios; Ratas

Citation/Cómo citar este artículo: Al-Okbi SY, Mohamed DA, Kandil E, Ahmed EK, Mohammed SE. 2014. Functional ingredients and cardiovascular protective effect of pumpkin seed oils. Grasas Aceites 65 (1): e007. doi: http://dx.doi. org/10.3989/gya.062813

Copyright: (C) 2014 CSIC. This is an open-access article distributed under the terms of the Creative Commons Attribution-Non Commercial (by-nc) Spain 3.0 Licence. 


\section{INTRODUCTION}

Hyperlipidemia is a predominant risk factor for cardiovascular diseases (CVD) which remains as one of the leading causes of death all over the world (Lim et al., 2012). It accounts for nearly 50\% of all deaths in the Western developed world (Rich, 2006). Populations that consume a diet high in saturated fats and cholesterol tend to have higher incidence of coronary heart disease. The high levels of plasma LDL (low density lipoprotein) or other atherogenic lipoproteins are a prerequisite for most forms of atherosclerosis (Carmena et al., 2004). Epidemiological studies have shown that, in European populations, a low concentration of plasma antioxidants increases the risk of developing coronary heart disease (Grey, 1986; Bruckdorfer, 1995). The World Health Organization recommends a reduction in dietary saturated fat and cholesterol intake to prevent hypercholesterolemia and CVD. Elevated ratios of triglycerides to HDL-Ch and T-Ch to HDL-Ch reflect atherogenicity and are considered risk factors for CVD (da Luz et al., 2008). Growing evidence suggests that oxidative stress plays a major role in the initiation of atherosclerosis through stimulating inflammation and cytokine production (FernándezRobredo et al., 2008). A change in the endothelial function is one of the most important factors that participate in the progression of atherosclerosis and cardiovascular diseases (Thorand et al., 2006). Reactive oxygen species have been reported to induce endothelial dysfunction (Stewart-Lee et al., 1995). Many studies in animals and human have demonstrated an association between the circulating cytokine, adiponectin, endothelial function and coronary artery diseases (Kumada et al., 2003; Ouchi et al., 2003; Shimabukuro et al., 2003; Tan et al., 2004; Ouchi et al., 2006). On the other hand, dyslipidemia and a pro-inflammatory and thrombogenic state (Saad and Gooren, 2009) are considered as components of metabolic syndrome that may lead to CVD.

Phytochemicals have received much interest in recent years because of their potential prevention and curing of chronic diseases. Food rich in phytochemicals and nutrients such as carotenoids, tocopherols, unsaturated fatty acids, phytosterols and phenolic compounds have been previously reported to have health benefits such as antioxidant, anti-inflammatory and hypolipidemic effects (Geetha et al., 2004; Ansari et al., 2005; Prakash and Gupta, 2009). Intervention by antioxidants has been shown to improve endothelial dysfunction and reduce lipoprotein oxidation (Stewart- Lee et al., 1995, Morel and Chisolm 1989) and thereby may prevent progression to atherosclerosis and CVD.

Phytosterols are proposed to have a wide spectrum of biological effects including anti-inflammatory, antioxidative (de Jong et al., 2003; Berger et al., 2004) and cholesterol lowering activities (de Jong et al., 2003).
Mixed $\alpha, \beta, \gamma$ and $\delta$ - tocopherols have been shown to have better antioxidant and anti-inflammatory effects than $\alpha$-tocopherol alone (Saldeen and Saldeen, 2005).

Polyunsaturated fatty acids (PUFAs) have numerous beneficial effects on CVD including improved blood lipid profile (Keys and Parlin, 1966) and antiinflammatory activity (Im, 2012).

The Pumpkin plant (Cucurbita sp.) of the Cucurbitaceae family is a native of Asia; however, it is now grown extensively in many of the temperate and warmer climates of the world. Species of pumpkin available include Cucurbita pepo (most common), Cucurbita maxima, Cucurbita stilbo. (Phillips et al., 2005) and Cucurbita moschata. Pumpkin seeds are rich in oil and the variability in the oil content is very high resulting from a broad genetic diversity. Twelve pumpkin cultivars (Cucurbita maxima D.), cultivated in Iowa, were shown to contain oil ranging from 10.9 to $30.9 \%$ of high oxidative stability (Stevenson et al., 2007). Pumpkin seed oil (PSO) is commonly used in folk medicine. It was shown in several countries that the incidence of hypertension, atherosclerosis, prostatic hypertrophy and urinary bladder hyperplasia was reduced in people regularly consuming the seed oil. Also pumpkin seeds are used locally in Eritrea to treat tapeworm (Harvath, 1988; Schiebel-Schlosser and Friederich, 1998; Zuhair et al., 2000, Dreikorn, 2002). PSO is rich in many antioxidants and beneficial nutritional supplements such as essential fatty acids (FAs), vitamins, squalene, carotenoids, tocopherols, phytoestrogenes, phytosterols, polyphenols, hydrocarbon, triterpenoids and selenium (Zambo, 1988; Murkovic et al., 1996; Fruehwirth and Hermetter, 2007; Gossell-Williams, 2008).

It is hypothesized that the effect of PSO from different origins may differ due to changes in their content of bioactive ingredients that may be attributed to their broad genetic diversity and environmental conditions, so it might be of interest to set a comparative study between them. So, the aim of the present research was to determine the functional ingredients including fatty acids, phytosterols and tocopherols in PSO in an Egyptain and European variety. The main aim was to evaluate the beneficial effects of such PSO on plasma lipid profiles, oxidative stress and adiponectin concentration in rats fed a hypercholesterolemic diet.

\section{MATERIALS AND METHODS}

\subsection{Materials}

\subsubsection{Plant materials}

Egyptian pumpkin seeds (Cucurbita moschata, L. Family Curcubitaceae) were purchased from the local market, Cairo, Egypt. The plant was authenticated by 
Dr/ Essam Mohamed Khalil, Researcher in Vegetable, Medicinal and Aromatic Plant Breeding Department, Horticulture Research Institute, Egypt. European PSO (Cucurbita pepo, L. Family Cucurbitaceae var. styria) was obtained from Graz, Austria.

\subsubsection{Animals}

Male white albino rats of body weight ranging from 80 to $100 \mathrm{~g}$ body weight were used in the present study. The animals were kept individually in stainless steel cages; water and food were given ad-libtium. The animal procedure was performed in accordance with the Ethics Committee of the National Research Centre, Cairo, Egypt, and followed the recommendations of the National Institutes of Health Guide for Care and Use of Laboratory Animals (Publication No. 85-23, revised 1985).

\subsection{Methods}

\subsubsection{Preparation of plant materials}

Pumpkin seeds were dried in an air-circulated oven at $40^{\circ} \mathrm{C}$ and reduced into powder.

\subsubsection{Preparation of $P S O$}

The dried powder of the seeds was placed in a Soxhlet and subjected to extraction using petroleum ether $\left(40-60{ }^{\circ} \mathrm{C}\right)$ to prepare the oil. The solvent was completely removed by evaporation under reduced pressure at a temperature not exceeding $40{ }^{\circ} \mathrm{C}$.

\subsubsection{Determination of tocopherols}

Tocopherols $(\alpha, \gamma$ and $\delta$ ) were determined in both Egyptain and European PSO using HPLC according to the method of Amaral et al. (2005).

HPLC conditions. An HPLC/Agilent model, Agilent $1100 \mathrm{G}$ 1311A Quat pump, G1322A Degasser, G 1329A Autosampler, G 1330A Chiller, G 1316A column compartment, fluorescence detector PC and Chemstation software were used along with an SI (150 x $4.6 \mathrm{~mm})$ column. The wave length of excitation was at $290 \mathrm{~nm}$ with emission at $330 \mathrm{~nm}$. The mobile phase was a mixture of hexane and isopropanol $(99: 1, \mathrm{v} / \mathrm{v})$, flow rate: $1 \mathrm{~mL} \cdot \mathrm{min}^{-1}$. The concentrations of $(\alpha, \gamma$ and $\delta$ ) -tocopherols in the samples were obtained by comparing their peak areas with the peak area of standards in relation to concentration.

\subsubsection{Assessment of FAs, hydrocarbon and phytosterol contents in Egyptian and European oils.}

The UNSAP fraction and FA methyl esters of PSO were prepared according to A.O.A.C (2000) for the determination of FAs, hydrocarbons and phytosterols using GLC.
The UNSAP fraction was analyzed by GLC adopting the following conditions: Column: 10\% OV-101 packed column; Stationary phase: Chromosorb W-HP; Detector temperature: $290{ }^{\circ} \mathrm{C}$; Injector temperature, $28{ }^{\circ} \mathrm{C}$; Carrier gas $\mathrm{N}_{2}$; flowrate $30 \mathrm{~mL} \cdot \mathrm{min}^{-1}$; air flow-rate: $300 \mathrm{~mL} \cdot \mathrm{min}^{-1} ; \mathrm{H}_{2}$ Flow-rate $30 \mathrm{~mL} \cdot \mathrm{min}^{-1}$; Detector FID; Chart speed: $0.5 \mathrm{~cm} \cdot \mathrm{min}^{-1}$; Oven program: Initial temperature, $70{ }^{\circ} \mathrm{C}$; Final temperature, $270{ }^{\circ} \mathrm{C}$; programmed $4{ }^{\circ} \mathrm{C} \cdot \mathrm{min}^{-1}$ for $35 \mathrm{~min}$ at $270{ }^{\circ} \mathrm{C}$, total time, $85 \mathrm{~min}$. The identification of hydrocarbons and sterol contents of the unsaponifiable matter was carried out by comparison of their retention times with co-injected authentic reference compounds. Quantification was based on peak area integration.

GLC analysis of the methyl ester was carried out according to the following conditions: Stationary phase: 10\% diethylene glycosuccinate (DEGS) packed column; oven temperature, $170{ }^{\circ} \mathrm{C}$; detector temperature, $300{ }^{\circ} \mathrm{C}$; injector temperature, $250{ }^{\circ} \mathrm{C}$; Carrier gas, $\mathrm{N}_{2}$; flow-rate, $30 \mathrm{~mL} \cdot \mathrm{min}^{-1}$; air flow-rate, $350 \mathrm{~mL} \cdot \mathrm{min}^{-1} ; \mathrm{H}$, flow-rate, $350 \mathrm{~mL} \cdot \mathrm{min}^{-1}$; detector, FID; Chart speed, $2 \mathrm{~cm} \cdot \mathrm{min}^{-1}$. Identification of the fatty acid methyl esters was carried out by the direct comparison of the retention times of each of the separated compounds with authentic samples of the fatty acid methyl esters analyzed under the same conditions. Quantification was based on peak area integration.

\subsubsection{Preparation of dosage form}

The oils were emulsified separately in water by gum acacia to adjust the dose carefully before given orally to rats. The vehicle was prepared to be given to the control rats by dissolving the same amount of gum acacia in water.

\subsubsection{Preparation of diets}

Balanced and hypercholesterolemic diets were prepared as shown in table (1). The hypercholesterolemic diet was designed as an intermediate between that reported by Matsumoto et al. (2004) and Mohammed et al. (2010). In the study by Matsumoto et al., the diet contained $20 \%$ beef tallow, $1.5 \%$ cholesterol and $1 \%$ sodium chlorate was used to induce hypercholesterolemia. In the study by Mohammed et al., the hypercholesterolemic diet contained $20 \%$ coconut oil, $1 \%$ cholesterol and $0.25 \%$ cholic acid.

\subsubsection{Design of the animal experiment}

Thirty-six male rats were divided into six groups of 6 rats each. The first was the normal group where the rats received a balanced diet throughout the study period (one month), all other remaining groups were fed a hypercholesterolemic diet. 
TABLE 1. Composition of different experimental diets $\left(\mathrm{g} 100 \mathrm{~g}^{-1}\right)$

\begin{tabular}{lcc}
\hline Ingredients & Balanced diet & $\begin{array}{c}\text { Hypercholesterolemic } \\
\text { diet }\end{array}$ \\
\hline Casein & $11.90^{*}$ & $11.90^{*}$ \\
Fat & & 20.00 \\
$\quad$ Sheep tallow & - & - \\
$\quad$ Sun-flower oil & 10.00 & 20.80 \\
Maize starch & 45.73 & 41.55 \\
Sucrose & 22.87 & - \\
Cellulose & 5.00 & 3.50 \\
Salt mixture & 3.50 & 1.00 \\
Vitamin mixture & 1.00 & 1.00 \\
Cholesterol & - & 0.25 \\
Sodium cholate & - & 100 \\
Total & 100 & \\
\hline
\end{tabular}

*11.9 g casein has been estimated to contain $10 \mathrm{~g}$ protein (AOAC, 1995).

One served as a hypercholesterolemic control group, whereas the other four groups were fed a hypercholesterolemic diet along with an oral administration of a daily dose of either Egyptian or European PSO as 40 and $500 \mathrm{mg} \cdot \mathrm{kg}^{-1}$ rat body weight throughout the study period. During the experiment, body weight and food intake were recorded once a week. At the end of the study, total food intake, body weight gain and food efficiency ratio (Body weight gain/total food intake) were calculated. Blood samples were collected from fasted animals for the determination of total plasma lipids (Zollner and kirsch, 1962), T-Ch (Watson, 1960), HDL-Ch (Burstein et al., 1970), low density lipoprotein cholesterol (LDL-Ch) (Gerard and Gerald, 1981) and TGs (Megraw et al., 1979). The T-Ch/HDL-Ch ratio and TGs/HDL-Ch ratio were calculated. Plasma malondialdehyde (MDA) was assessed as an indicator of lipid peroxidation (Satoh, 1978). The plasma levels of vitamin E were determined according to the method of Desai and Machlin (1985). The plasma levels of adiponectin were estimated using the ELISA technique as a biomarker of inflammation (Mouse/Rat HMW Adiponectin ELISA kit, Code No.: AKMAN-011, manufactured by Shibayagi Co., Ltd., Japan. The antibody is specific to rats), a method similar to that used in humans, according to Ryan (2003).

\subsubsection{Statistical analysis}

The results of the animal experiments were expressed as the Mean \pm SEM and they were analyzed statistically using one-way analysis of variance ANOVA followed by the LSD test. In all cases $p<0.05$ was used as the criterion of statistical significance.

\section{RESULTS}

\subsection{FAs, hydrocarbon and phytosterol contents in PSO}

Tables 2 and 3 show the FA and UNSAP in the oils, respectively. The results of the total FA analysis revealed that linoleic acid was the major unsaturated FA in the oils; it was present at 38.9 and $43.7 \%$ of the total FAs in European and Egyptian PSO, respectively. Oleic acid was present in low amounts (3.5 and 5.1 in European and Egyptian varieties, respectively). Palmitic acid was the major saturated FA in the oils where it was present at $5.8 \%$ in European and $10.9 \%$ in the Egyptian type. Stearic acid was present in very low percentage in both oils. The GLC investigation of the UNSAP showed the presence of stigmasterol in a high percent $(29.7 \%$ of UNSAP) in European PSO. Beta-Sitosterol was present as 3.4\% in the Egyptian variety oil. Campesterol was present in both European and Egyptian varieties as 13.9 and $2.2 \%$, respectively. Total phytosterol was extremely high in the European seed oil $43.6 \%$ compared to the Egyptian oil $(5.6 \%)$. The major hydrocarbon was $\mathrm{C} 20$ in the European oil $(6 \%)$ and $\mathrm{C} 22$ in the Egyptian PSO (4.1\%).

\subsection{Tocopherol contents in PSO}

Total tocopherol level in the European variety $\left(275.08 \mathrm{mg} \cdot 100 \mathrm{~g}^{-1}\right)$ was higher than that in the Egyptian (111.95 mg·100 $\left.\mathrm{g}^{-1}\right)$. Alpha-tocopherol was present in the two oils, the European pumpkin seed oil showed a higher content $\left(273.5 \mathrm{mg} \cdot 100 \mathrm{~g}^{-1}\right)$ than the Egyptain oil $\left(108 \mathrm{mg} \cdot 100 \mathrm{~g}^{-1}\right)$. Gammatocopherol was present only in the Egyptain variety as $3.95 \mathrm{mg} \cdot 100 \mathrm{~g}^{-1}$ while $\delta$-tocopherol exists only in the European variety $\left(1.58 \mathrm{mg} \cdot 100 \mathrm{~g}^{-1}\right)$.

\subsection{Biological evaluation of PSO}

Concerning the animal experiment, non-significant differences were observed between the different groups in final body weight, body weight gain and the food efficiency ratio (Table 4). The total food intake was significantly lower in the groups treated with PSO

TABLE 2. Identified Fatty acids contents of pumpkin seed oils (as percentage of total fatty acids)

\begin{tabular}{lcc}
\hline Fatty Acids & European oil & Egyptian oil \\
\hline Palmitic Acid (C16:0) & 5.80 & 10.90 \\
Linoleic Acid (C18:2) & 38.90 & 43.70 \\
Oleic Acid (C18:1) & 3.50 & 5.10 \\
Stearic Acid (C18:0) & 0.20 & 0.14 \\
Total Saturated F.A & 6.00 & 11.04 \\
Total Unsaturated F.A & 42.40 & 48.80 \\
\hline
\end{tabular}


TABLE 3. GLC analysis of unsaponifiable matter of pumpkin seed oils (as percentages of total unsaponifiable matter)

\begin{tabular}{lcc}
\hline $\begin{array}{l}\text { Hydrocarbons } \\
\text { and sterols }\end{array}$ & European PSO & Egyptian PSO \\
\hline C15 & 0.05 & - \\
C16 & 0.09 & 0.01 \\
C18 & 0.15 & 0.15 \\
C19 & 3.86 & 3.11 \\
C20 & 6.08 & - \\
C21 & 0.69 & - \\
C22 & 4.25 & 4.11 \\
C23 & - & - \\
C24 & 0.45 & - \\
C25 & 3.23 & - \\
C26 & 3.29 & - \\
C27 & 4.44 & - \\
C28 & 3.87 & - \\
Total Identified & 30.45 & 7.38 \\
Hydrocarbons & & \\
Campesterol & 13.90 & 2.20 \\
Stigmasterol & 29.70 & - \\
Beta-sitosterol & - & 3.40 \\
Total Identified & 43.60 & 5.60 \\
phytosterols & & \\
\hline
\end{tabular}

in different doses compared to the normal and hypercholesterolemic groups.

The plasma levels of total lipids, T-Ch, LDL-Ch, TGs and the ratios of TGs/HDL-Ch and T-Ch/ HDL-Ch of the control hypercholesterolemic rats showed significant elevation by $171,222,749,111$, 282 and $482 \%$, respectively compared to the normal control. HDL-Ch in the control hypercholesterolemic rats was significantly reduced by $45 \%$ compared to the normal control group (Table 5). The control hypercholesterolemic rats showed an increase in oxidative stress reflected by the significant reduction in plasma vitamin $E$ and significant elevation in plasma MDA level by 52 and $112 \%$, respectively, compared to the normal control. In addition, the plasma level of adiponectin was reduced significantly in the control hypercholesterolemic rats compared to the normal control by $8 \%$. High and low doses of Egyptian PSO exerted a significant reduction in plasma lipid parameters compared to the hypercholesterolemic control as shown in total lipid, T-Ch, LDL-Ch, TGs and the ratios of TGs/HDL-Ch and T-Ch/HDL-Ch by $30,33,42,41,63$ and $59 \%$, respectively in the case of high dose, respectively and by 19, 17, 21, 26,43 , and $36 \%$, in the rats receiving the low dose. A high European oil dose showed a significant reduction in plasma lipid parameters namely total lipids, T-Ch TGs, LDL-Ch, and the ratios of T-Ch/ HDL-Ch. and TGs/HDL-Ch (22, 36, 44, 45, 60 and $65 \%$, respectively) compared to the hypercholesterolemic control. A low dose of European PSO also had similar but lower effects on the aforementioned parameters (Percentage reduction was 15, 18, 31, 23, 42 and 51, respectively). Plasma HDL-Ch was significantly elevated on administration of either Egyptian or European PSO compared to the hypercholesterolemic control.

Plasma vitamin E was significantly elevated while plasma adiponectin was significantly increased in all rats given the oil compared to the hypercholesterolemic control. The percentage increase in vitamin $\mathrm{E}$ and adiponectin in the groups given a high dose of either Egyptain or European oil compared to the hypercholesterolemic group was $72 \%$, and $9 \%$, respectively. The percentage increase in adiponectin was 7 and $8 \%$ in the case of rats given the low dose of PSO of Egyptian and European oils compared to the control hypercholesterolemic rats. The $\%$ increase in vitamin $\mathrm{E}$ was 41 and 39\% in Egyptian and European low doses, respectively.

The Plasma MDA level was reduced significantly in the rats given either Egyptian (high and low doses) or European oils (high and low doses) by $35,28,34$ and $26 \%$, respectively compared to the control hypercholesterolemic rats. The Egyptian and European oil high doses matched each other in more than one parameter namely HDL-Ch, T-Ch, LDL-Ch, vitamin E, MDA, adiponectin and the

TABLE 4. Nutritional parameters of different experimental groups (mean \pm SEM)

\begin{tabular}{lccccrr}
\hline & $\begin{array}{c}\text { Normal } \\
\text { control } \\
\mathbf{n = 6}\end{array}$ & $\begin{array}{c}\text { Hypercholesterolemic } \\
\mathbf{c o n t r o l} \\
\mathbf{n = 6}\end{array}$ & $\begin{array}{c}\text { Egptian high } \\
\text { dose oil } \\
\mathbf{n = 6}\end{array}$ & $\begin{array}{c}\text { Egyptian low } \\
\text { Pose oil } \\
\mathbf{n = 6}\end{array}$ & $\begin{array}{c}\text { European high } \\
\text { dose oil } \\
\mathbf{n = 6}\end{array}$ & $\begin{array}{c}\text { European low } \\
\text { dose oil } \\
\mathbf{n = 6}\end{array}$ \\
\hline Initial body weight $(\mathrm{g})$ & $93.00^{\mathrm{a}} \pm 3.76$ & $92.70^{\mathrm{a}} \pm 3.34$ & $93.17^{\mathrm{a}} \pm 3.94$ & $92.70^{\mathrm{a}} \pm 3.16$ & $93.17^{\mathrm{a}} \pm 2.33$ & $92.70^{\mathrm{a}} \pm 2.42$ \\
Final body weight $(\mathrm{g})$ & $176.50^{\mathrm{a}} \pm 9.64$ & $177.00^{\mathrm{a}} \pm 7.39$ & $164.50^{\mathrm{a}} \pm 9.36$ & $175.00^{\mathrm{a}} \pm 6.37$ & $164.17^{\mathrm{a}} \pm 6.51$ & $174.17^{\mathrm{a}} \pm 3.94$ \\
Body weight gain $(\mathrm{g})$ & $83.50^{\mathrm{a}} \pm 9.44$ & $84.33^{\mathrm{a}} \pm 7.52$ & $71.33^{\mathrm{a}} \pm 6.48$ & $82.33^{\mathrm{a}} \pm 3.67$ & $71.00^{\mathrm{a}} \pm 6.54$ & $81.50^{\mathrm{a}} \pm 6.27$ \\
Total food intake $(\mathrm{g})$ & $376.5^{\mathrm{a}} \pm 6.22$ & $372.33^{\mathrm{a}} \pm 4.11$ & $334.83^{\mathrm{c}} \pm 13.03$ & $341.50^{\mathrm{bc}} \pm 6.86$ & $337.00^{\mathrm{bc}} \pm 9.35$ & $360.00^{\mathrm{ab}} \pm 6.47$ \\
Food intake g/day & $13.45^{\mathrm{a}} \pm 0.22$ & $13.30^{\mathrm{a}} \pm 0.147$ & $11.96^{\mathrm{c}} \pm 0.47$ & $12.20^{\mathrm{bc}} \pm 0.245$ & $12.04^{\mathrm{bc}} \pm 0.33$ & $12.86^{\mathrm{ab}} \pm 0.23$ \\
Food efficiency ratio $(\mathrm{g})$ & $0.22^{\mathrm{a}} \pm 0.03$ & $0.23^{\mathrm{a}} \pm 0.02$ & $0.21^{\mathrm{a}} \pm 0.02$ & $0.24^{\mathrm{a}} \pm 0.01$ & $0.21^{\mathrm{a}} \pm 0.02$ & $0.23^{\mathrm{a}} \pm 0.01$ \\
\hline
\end{tabular}

In each row the same letter means non-significant difference while different letters mean significant differences at 0.05 probability. 
TABLE 5. Plasma parameters of different experimental groups (mean \pm SEM)

\begin{tabular}{|c|c|c|c|c|c|c|}
\hline Parameters & Normal control & $\begin{array}{c}\text { Hypercholesterolemic } \\
\text { control }\end{array}$ & $\begin{array}{c}\text { Egyptian high } \\
\text { dose oil }\end{array}$ & $\begin{array}{c}\text { Egyptian low } \\
\text { dose oil }\end{array}$ & $\begin{array}{l}\text { European high } \\
\text { dose oil }\end{array}$ & $\begin{array}{c}\text { European low } \\
\text { dose oil }\end{array}$ \\
\hline $\begin{array}{l}\text { Total lipids }\left(\mathrm{mg} \mathrm{dL}^{-1}\right) \\
\% \text { Change }\end{array}$ & $373.48^{f} \pm 7.52$ & $\begin{array}{c}1013.78^{\mathrm{a}} \pm 11.25 \\
171\end{array}$ & $\begin{array}{c}710.67^{\mathrm{e}} \pm 14.79 \\
-30\end{array}$ & $\begin{array}{c}825.32^{\mathrm{c}} \pm 8.90 \\
-19\end{array}$ & $\begin{array}{c}792.42^{\mathrm{d}} \pm 12.42 \\
-22\end{array}$ & $\begin{array}{c}858.32^{\mathrm{b}} \pm 11.94 \\
-15\end{array}$ \\
\hline $\begin{array}{l}\text { Total- Ch }\left(\mathrm{mg} \mathrm{dL}^{-1}\right) \\
\% \text { Change }\end{array}$ & $90.00^{\mathrm{d}} \pm 1.32$ & $\begin{array}{c}289.42^{\mathrm{a}} \pm 3.82 \\
222\end{array}$ & $\begin{array}{c}193.25^{\mathrm{c}} \pm 5.23 \\
-33\end{array}$ & $\begin{array}{c}239.08^{\mathrm{b}} \pm 4.17 \\
-17\end{array}$ & $\begin{array}{c}185.25^{\mathrm{c}} \pm 3.64 \\
-36\end{array}$ & $\begin{array}{c}236.17^{\mathrm{b}} \pm 2.44 \\
-18\end{array}$ \\
\hline $\begin{array}{l}\text { HDL- Ch }\left(\mathrm{mg} \mathrm{dL}^{-1}\right) \\
\% \text { Change }\end{array}$ & $45.46^{\mathrm{a}} \pm 0.77$ & $\begin{array}{c}25.22^{\mathrm{d}} \pm 0.81 \\
45\end{array}$ & $\begin{array}{l}40.55^{\mathrm{b}} \pm 0.78 \\
61\end{array}$ & $\begin{array}{c}32.76^{\mathrm{c}} \pm 1.12 \\
30\end{array}$ & $\begin{array}{c}39.87^{\mathrm{b}} \pm 1.04 \\
58\end{array}$ & $\begin{array}{c}35.56^{\mathrm{c}} \pm 1.64 \\
41\end{array}$ \\
\hline $\begin{array}{l}\text { LDL- Ch }\left(\mathrm{mg} \mathrm{dL}^{-1}\right) \\
\% \text { Change }\end{array}$ & $26.69^{\mathrm{d}} \pm 1.26$ & $\begin{array}{c}226.59^{\mathrm{a}} \pm 3.48 \\
749\end{array}$ & $\begin{array}{c}130.34^{c} \pm 5.73 \\
-42\end{array}$ & $\begin{array}{c}178.51^{\mathrm{b}} \pm 4.55 \\
-21\end{array}$ & $\begin{array}{c}124.45^{\mathrm{c}} \pm 4.36 \\
-45\end{array}$ & $\begin{array}{c}174.71^{\mathrm{b}} \pm 3.27 \\
-23\end{array}$ \\
\hline $\begin{array}{l}\text { TGs }\left(\mathrm{mg} \mathrm{dL}^{-1}\right) \\
\% \text { Change }\end{array}$ & $89.24^{\mathrm{f}} \pm 1.79$ & $\begin{array}{c}188.08^{\mathrm{a}} \pm 2.65 \\
111\end{array}$ & $\begin{array}{c}111.81^{\mathrm{d} \pm 1.15} \\
-41\end{array}$ & $\begin{array}{c}139.07^{\mathrm{b}} \pm 2.87 \\
-26\end{array}$ & $\begin{array}{c}104.66^{\mathrm{e}} \pm 1.62 \\
-44\end{array}$ & $\begin{array}{c}129.45^{\mathrm{c}} \pm 1.41 \\
-31\end{array}$ \\
\hline $\begin{array}{l}\text { Total -Ch/ HDL-Ch } \\
\left(\mathrm{mg} \mathrm{dL}^{-1}\right) \\
\% \text { Change }\end{array}$ & $1.98^{\mathrm{d}} \pm 0.03$ & $\begin{array}{l}11.54^{\mathrm{a}} \pm 0.41 \\
482\end{array}$ & $\begin{array}{c}4.78^{c} \pm 0.20 \\
-59\end{array}$ & $\begin{array}{c}7.35^{\mathrm{b}} \pm 0.32 \\
-36\end{array}$ & $\begin{array}{c}4.67^{c} \pm 0.19 \\
-60\end{array}$ & $\begin{array}{l}6.72^{b} \pm 0.34 \\
\quad-42\end{array}$ \\
\hline 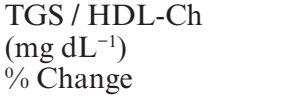 & $1.97^{\mathrm{e}} \pm 0.05$ & $\begin{array}{l}7.50^{\mathrm{a}} \pm 0.31 \\
282\end{array}$ & $\begin{array}{c}2.76^{\mathrm{d}} \pm 0.07 \\
-63\end{array}$ & $\begin{array}{l}4.28^{b} \pm 0.20 \\
-43\end{array}$ & $\begin{array}{c}2.64^{\mathrm{d}} \pm 0.09 \\
-65\end{array}$ & $\begin{array}{c}3.68^{\mathrm{c}} \pm 0.19 \\
-51\end{array}$ \\
\hline $\begin{array}{l}\left.\text { MDA(nmol mL } \mathrm{mL}^{-1}\right) \\
\% \text { Change }\end{array}$ & $7.74^{\mathrm{d}} \pm 0.38$ & $\begin{array}{l}16.42^{\mathrm{a}} \pm 0.47 \\
112\end{array}$ & $\begin{array}{c}10.68^{\mathrm{c}} \pm 0.44 \\
-35\end{array}$ & $\begin{array}{c}11.86^{\mathrm{bc}} \pm 0.78 \\
-28\end{array}$ & $\begin{array}{c}10.80^{\mathrm{c}} \pm 0.40 \\
-34\end{array}$ & $\begin{array}{c}12.19^{b} \pm 0.19 \\
-26\end{array}$ \\
\hline $\begin{array}{l}\text { Vitamin } \mathrm{E}\left(\mathrm{mg} \mathrm{dL}^{-1}\right) \\
\% \text { Change }\end{array}$ & $1.07^{\mathrm{a}} \pm 0.05$ & $\begin{array}{l}0.51^{\mathrm{d}} \pm 0.03 \\
\quad-52\end{array}$ & $\begin{array}{l}0.88^{\mathrm{b}} \pm 0.03 \\
72\end{array}$ & $\begin{array}{c}0.72^{\mathrm{c}} \pm 0.01 \\
41\end{array}$ & $\begin{array}{c}0.88^{\mathrm{b}} \pm 0.02 \\
72\end{array}$ & $\begin{array}{l}0.71^{\mathrm{c}} \pm 0.01 \\
39\end{array}$ \\
\hline $\begin{array}{l}\text { Adiponectin }\left(\mathrm{ng} \mathrm{mL}^{-1}\right) \\
\% \text { Change }\end{array}$ & $5060.00^{\mathrm{a}} \pm 62.01$ & $\begin{array}{c}4643.33^{\mathrm{b}} \pm 45.28 \\
-8\end{array}$ & $\begin{array}{c}5038.33^{\mathrm{a}} \pm 70.10 \\
9\end{array}$ & $\begin{array}{c}4973.33^{\mathrm{a}} \pm 40.63 \\
7\end{array}$ & $\begin{array}{c}5041.67^{\mathrm{a}} \pm 23.00 \\
9\end{array}$ & $\begin{array}{c}5010.00^{\mathrm{a}} \pm 44.34 \\
8\end{array}$ \\
\hline
\end{tabular}

In each row the same letter means non-significant difference while different letters mean significant differences at 0.05 probability. $\%$ change in the column of hypercholesterolemic control was calculated by comparing the hypercholesterolemic control with the normal control.

$\%$ change in the last 4 columns was calculated by comparing the hypercholesterolemic groups given PSO with the hypercholesterolemic control.

ratios of T-Ch/HDL-Ch and TGs/HDL-Ch. Also, the Egyptian and European oil low doses showed the same phenomenon for the aforementioned parameters except for TGs/HDL-Ch.

It is worthy to mention that the plasma adiponectin of the groups given PSOs showed non-significant difference compared to the normal control while all the other plasma parameters, although improved, were still significantly different from the normal rats.

\section{DISCUSSION}

The present study was postulated to assess the usefulness of PSO in alleviating the risks of CVD that may be associated with a hypercholesterolemic diet. The tocopherol, phytosterol, and the FA contents of both the Egyptian and European PSO were determined. The beneficial effects of low and high doses of such oils towards plasma lipid profile, oxidative stress and adiponectin (an inflammatory biomarker) in the rats fed a hypercholesterolemic diet were monitored.

The hypercholesterolemic diet used in the present study produced dyslipidemia reflected by a significant elevation of plasma total lipids, total cholesterol, triglycerides and LDL-cholesterol with a significant reduction in HDL-Ch. The significant increase in TGs/ HDL-Ch, T-Ch/HDL-Ch, and the significant reduction in the plasma levels of HDLcholesterol in hypercholesterolemic rats in the present study were in agreement with those reported previously (Yang et al., 2006). The elevation in the ratios of TGs/HDL-Ch and T-Ch/HDL-Ch are considered as atherogenic factors that may lead to atherosclerosis (Yang et al., 2006; da Luz et al., 2008). The administration of PSO with different doses produced a significant reduction in these ratios compared with the hypercholesterolemic control rats but still significantly higher than normal. This anti-atherogenic property of PSO may be mediated by the high concentration of linoleic acid which exists in PSO as demonstrated by Makni et al. (2008). Epidemiological studies have shown that the probability of coronary artery disease decreases linearly with the high content of the unsaturated fatty acids in the food stuff (Key, 1970). A reduction in LDL-Ch can reduce cardiovascular events by up to $60 \%$ (Law et al., 2003). Dietary components that directly lower LDL-Ch are important for reducing CVD risk. From the present study and from previous literature PSO was shown to contain phytosetrol, unsaturated FAs, phenolic compounds and 
carotenoids which collectively possess lipid lowering and antioxidant and anti-inflammatory effects (Van Hoed et al., 2002; Matus et al., 1993).

Hypercholesterolemia induces oxidative stress by causing a reduction in the antioxidant enzymatic defense potential of tissues and the generation of oxygen free radicals. As a result of these metabolic events, peroxidation reactions are accelerated, leading to cellular injury and atherosclerosis (Gokkusu and Mostafazadeh, 2003). The elevation in oxidative stress in hypercholesterolemic control rats in the current study was reflected by a reduction in plasma vitamin $\mathrm{E}$ as an indicator of antioxidant status and the elevation of MDA as an indicator of lipid peroxidation. The oral administration of both PSOs prevented the elevation of oxidative stress through amelioration of the previously mentioned parameters. These results were explained in the light of PSO antioxidant properties (Zuhair et al., 2000) that may be related to the presence of phytosterols and $\alpha, \gamma$ and $\delta$ tocopherols that could serve as antioxidants.

Hypercholesterolemia was accompanied by a reduction in adiponectin levels in the control hypercholesterolemic rats indicating inflammation in adipose tissue in the present study. Administration of any of the studied oils significantly elevated adiponectin levels in the rats fed the hypercholesterolemic diet indicating an anti-inflammatory activity of PSO. Adiponectin is a novel cytokine secreted from adipose tissue (Chandran et al., 2003) and is normally present in human plasma at concentrations up to $30 \mu \mathrm{g} / \mathrm{ml}$ but is markedly lower in association with obesity-linked diseases including coronary artery disease and type 2 diabetes (Hotta et al., 2000). Clinical observations have demonstrated that hypoadiponectinemia is closely related to endothelial dysfunction in peripheral arteries (Shimabukuro et al., 2003; Tan et al., 2004) and that plasma total adiponectin concentrations are inversely related to the risk of myocardial infarction (Pischon et al., 2004). These results suggest that PSO might improve endothelial dysfunction which is manifested by elevating adiponectin and thereby protect from the occurrence of coronary artery diseases.

The improvement in plasma lipid profile, oxidative stress and adiponectin levels in the rats fed the hypercholesterolemic diet and given both PSOs may be attributed to the presence of tocopherols, phytosterols and unsaturated FAs determined in the present study. PSO has been previously shown to contain high levels of tocopherols (Van Hoed et al., 2009) which render it antioxidant activity and thus may be capable of reducing lipid peroxidation and act as an antioxidant. PSO is rich in n-6 PUFA that has been proven to have an anti-atherogenic effect in rats maintained on a high fat diet for 5 months as reported by Kim et al. (2012).

Phytosterols have been shown to decrease LDL$\mathrm{Ch}$ in hypercholesterolemic subjects by suppressing cholesterol absorption (Vanstone et al., 2002; Alhassan et al., 2006). The intake of plant sterols has been shown to confer a healthier lipid profile and ameliorate cardiovascular disease risk factors (Ziv et al., 2009).

Phytosterol concentration was reported to be $24.9 \mathrm{mg} \cdot 100 \mathrm{~g}^{-1}$ in pumpkin seed (Ryan et al., 2007). It was reported by Ryan et al. (2007) that the level of $\beta$-sitosterol was $24.9 \mathrm{mg} \cdot 100 \mathrm{~g}^{-1}$, and stigmasterol was $8.4 \mathrm{mg} \cdot 100 \mathrm{~g}^{-1}$ in PSO while campesterol was not detected. Philips et al. (2005) indicated that pumpkin seed kernel contains $\beta$-sitosterol as $13.1 \mathrm{mg} \cdot 100 \mathrm{~g}^{-1}$ and that PSO contains $241 \mathrm{mg} \cdot 100 \mathrm{~g}^{-1}(>90 \%)$ of other sterols. In the present study, the predominant phytosterol in Egyptian PSO was $\beta$-sitosterol while in the European oil, it was stigmasterol.

The four dominant fatty acids in pumpkin seeds are palmitic $(13.3 \%)$, stearic $(8 \%)$, oleic $(29 \%)$ and linoleic $(47 \%)$. These four fatty acids make up $98 \pm 0.13 \%$ of the total amount of fatty acids; others being found at levels well below $0.5 \%$. The oil contains an appreciable amount of unsaturated fatty acids $(78 \%)$ and was found to be a rich source of linoleic acid (Murkovic et al., 1996 a; El-Adawey and Taha, 2001; Younis et al., 2000; Rayan et al., 2007). The fatty acids found in PSOs in the present study were palmitic, stearic, oleic and linoleic. In the current study both PSOs contain high percentages of unsaturated FA represented by linoleic acid. Saturated FAs were very low compared to unsaturated FAs, the main saturated FA was palmitic acid. These results agree with the results obtained by Bravi et al. (2006). Previous studies have shown that in the varieties used for oil production, palmitic occurs in the range of $10.3-11.7 \%$, stearic $4.1-5.4 \%$, oleic $30.5-40.8 \%$ and linoleic 42.1-51.5\% (Wenzel, 1987). In the present study, palmitic \% of the Egyptain variety was similar to the abovementioned study. The Egyptian PSO has linoleic acid as $43.7 \%$, however stearic and oleic showed much lower percentages than the aforementioned study. This may be due to the broad genetic diversity of PSO.

The total percentage of unsaturated FA was 81.6-82.7\% in the PSO of C. pepo, a German variety (Cerny et al., 1971; Wenzel, 1987). These previous $\%$ were higher than that in the present study. Younis et al. (2000) reported that the level of linoleic acid was $43-50 \%$ while it was $36.6-60.8 \%$ in other European varieties, (Murkovic et al., 1996a, 1996b). In the present study the level of linoleic acid in both Egyptian and European varieties falls within the latter range.

It was reported that the consumption of soybean oil containing $50 \%$ linoleic acid significantly reduced the mortality rate due to coronary artery disease (Younis et al., 2000). This may reflect the beneficial effect of linoleic acid in PSO towards CVD. 
Both PSO used in the present study contain oleic acid, which previously showed benefits on early events in atherosclerosis (Carluccio et al., 1999) because it decreased lipoprotein susceptibility to oxidation (Tsimikas et al., 1999). Oleic acid may prevent endothelium activation either by inhibiting the expression of adhesion molecules or by affecting nitric oxide production (Christon, 2003). The presence of carotenoids in PSO (Younis et al., 2000) may share in the cardio-protective effect as reported previously (Melendez-Martinez et al., 2004).

The reduction in oxidative stress, elevation of adiponectin and improvement in plasma lipid profile due to the oral administration of both oils may also be ascribed to the presence of phenolic compounds (Fruehwirth and Hermetter, 2007) that have been reported to have antioxidant, antiinflammatory and hypocholesterolemic activity (Löliger, 1991).

The tocopherol content in PSO may also contribute to the benefits observed, since tocopherol supplementation provides cardiovascular protection attributed to antioxidant mechanisms and peroxyl radical scavengering activity (Yamauchi, 2007). Knekt et al., (1994) and Kushi et al., (1996) demonstrated that the tocopherol content in food is inversely associated with mortality from cardiovascular disease.

It was reported previously that the $\gamma$-tocopherol content in PSO, which is about $5-10$ times as much as that of $\alpha$-tocopherol, varies over a broad range (41-620 $\mathrm{mg} \cdot \mathrm{kg}^{-1}$ dry pumpkin seeds). $\beta$ - and $\delta$-tocopherol were found at low levels (Murkovic et al., 1996b). In the present study $\alpha$-tocopherol was higther than $\gamma$ - tocopherol in the Egyptain variety and higher than $\delta$-tocopherol in the European variety.

In the current study, despite the difference in the contents of FAs, phytosterols and tocopherols of the Egyptian and European oils, they showed significant comparable improvements in plasma lipid profile, antioxidant status, lipid peroxidation parameters and adiponectin levels compared to the hypercholesterolemic rat group. It was noticed that a high dose of Egyptian and European PSO produced a much better effect than the low one.

It can be concluded that the Egyptian and European PSO produced an improvement in plasma lipid profile, adiponectin and antioxidant status. Both PSO produced reduction in plasma $\mathrm{T}-\mathrm{Ch} /$ HDL-Ch and TG/HDL-Ch that may afford protection from atherosclerosis and CVD. The cardioprotective effect of PSO may be due to the presence of a high percentage of USFA, phytosterols and tocopherols determined in the present study in addition to the phenolic compounds and carotenoids described previously.

\section{REFERENCES}

Alhassan S, Reese KA, Mahurin J, Plaisance EP, Hilson BD, Garner JC, Wee SO, Grandjean PW. 2006. Blood lipid responses to plant stanol ester supplementation and aerobic exercise training. Metabolism. 55, 541-549.

Amaral JS, Casal S, Torres D, Seabra RM, Oliveira BP. 2005. Simultaneous determination of tocopherols and tocotrienols in hazelnuts by a normal phase liquid chromatographic method. Anal. Sci. 21, 1545-1548.

Ansari NM, Houlihan L, Hussain B, Pieroni A, 2005. Antioxidant activity of five vegetables traditionally consumed by South-Asian migrants in Bradford, Yorkshire, UK. Phytother. Res. 19, 907-911.

A.O.A.C. 2000. Official Methods of Analysis (1 $17^{\text {th }}$ ed.). (Association of Official Agricultural Chemists, Gaithersburg, MD).

Berger A, Jones PJH, Abumweis SS. 2004. Plant sterols: factors affecting their efficacy and safety as functional food ingredients. Lipids Health Dis. 3, 5-24.

Bravi E, Perretti G, Montanari L. 2006. Fatty acids by high-performance liquid chromatography and evaporative light-scattering detector. J. Chromatogr. A. 1134, 210-214.

Bruckdorfer KR. 1995. Antioxidants and cardiovascular disease. Vasc. Med. Rev. 6, 1-6.

Burstein M, Scholnick HR, Morfin R. 1970. Rapid method for the isolation of lipoproteins from human serum by precipitation with polyanions. J. Lipid Res. 11, 583-595.

Carmena R, Duriez P, Fruchart JC. 2004. Atherogenic lipoprotein particles in atherosclerosis. Circulation. 109 (23 Suppl 1), III2-III7.

Carluccio MA, Massaro M, Bonfrate C, Siculella L, Maffia M, Nicolardi G, Distante A, Storelli C, De Caterina R. 1999. Oleic acid inhibits endothelial activation: direct vascular antiatherogenic mechanism of a nutritional component in the Mediterranean diet. Arterioscler. Thromb. Vasc. Biol. 19, 220-228.

Cerny, K, Korydylas, M, Pospisil, F, Svabensk, O, Zajiir, B. 1971. British J. Nutrit. 26, 293-298.

Chandran M, Phillips SA, Ciaraldi T, Henry RR. 2003. Adiponectin: more than just another fat cell hormone? Diabetes Care 26, 2442-2450.

Christon RA. 2003. Mechanisms of action of dietary fatty acids in regulating the activation of vascular endothelial cells during atherogenesis. Nutr. Rev. 61, 272-279.

da Luz PL, Favarato D, Faria-Neto JR Jr, Lemos P, Chagas AC. 2008. High ratio of triglycerides to HDL-cholesterol predicts extensive coronary disease. Clinics (Sao Paulo). 63, $427-432$.

de Jong A, Plat J, Ltjohann D, Mensink RP. 2008. Effects of long-term plant sterol or stanol ester consumption on lipid and lipoprotein metabolism in subjects on statin treatment. Brit. J. Nutr. 100, 937-941.

Desia ID, Machlin LJ. 1985. Vitamin E. In: Methods of Vitamin Assay. (eds. J. Augustin, B.P. Klein, D. Becker, P.B. Venugopal). $4^{\text {th }}$ edition. A widely Interscience Publication John Wiley and Sons, New York, pp. 255-275.

Dreikorn K 2002. The role of phytotherapy in treating lower urinary tract symptoms and benign prostatic hyperplasia. World J. Urol. 19, 426-435.

El-Adawy TA, Taha KM. 2001. Characteristics and composition of watermelon, pumpkin, and paprika seed oils and flours. J. Agric. Food Chem. 49, 1253-1259.

Fernández-Robredo P, Rodriguez JA, Sádaba LM, Recalde S, Garcì-Layana A. 2008. Egg Yolk improves lipid profile, lipid peroxidation and retinal abnormalities in a murine model of genetic hypercholesterolemia. J. Nutr. Biochem. $19,40-48$.

Fruehwirth GO, Hermetter A. 2007. Seeds and oil of the Styrian oil pumpkin: components and biological activities. Eur. J. Lipid Sci. Tech. 109, 1128-1140.

Geetha T, Garg A, Chopra K, Pal I. 2004. Delineation of antimutagenic activity of catechin, epicatechin and green tea extract. Mutat Res. 22; $556(1-2), 65-74$. 
Gerard T, Gerald AL. 1981. Process and reagents for the selective separation of low density lipoprotein (LDL) and for the quantification of their components. Eur. Path. (Appl.) E.P. 76, 211-223.

Gey GF. 1986. On the antioxidant hypothesis with regard to atherosclerosis. Bilb. Nutr. Dieta. 37, 53-91.

Gokkusu C, Mostafazadeh T. 2003. Changes of oxidative stress in various tissues by long-term administration of vitamin E in hypercholesterolemic rats. Clin. Chim. Acta 328, $155-161$.

Gossell-Williams M, Lyttle K, Clarke T, Gardner M, Simon O Phytother Res. 2008. Supplementation with pumpkin seed oil improves plasma lipid profile and cardiovascular outcomes of female non-ovariectomized and ovariectomized Sprague-Dawley rats. 22 (7), 873-877.

Harvath S, Bedo Z. 1988. Another possibility in treatment of hyperlipidemia with peponen of natural active sub-stance. Mediflora. 89, 7-8.

Hotta K, Funahashi T, Arita Y, Takahashi M, Matsuda M, Okamoto Y, Iwahashi H, Kuriyama H, Ouchi N, Maeda K, Nishida M, Kihara S, Sakai N, Nakajima T, Hasegawa K, Muraguchi M, Ohmoto Y, Nakamura T, Yamashita S, Hanafusa T, Matsuzawa Y. 2000. Plasma concentrations of a novel, adipose-specific protein, adiponectin, in type 2 diabetic patients. Arterioscler Thromb. Vasc. Biol. 20, $1595-1599$.

Im DS. 2012. Omega-3 fatty acids in anti-inflammation (proresolution) and GPCRs. Prog Lipid Res. 1 (3), 232-237.

Keys A. 1970. Coronary heart disease in seven countries. Circulation 41 (4 Suppl), 1-200.

Keys A, Parlin RW. 1966. Serum- cholesterol response to changes in dietary lipids. Am. J. Clin. Nutr. 19, 175-181.

Kim EH, Bae JS, Hahm KB, Cha JY. 2012. Endogenously synthesized n-3 polyunsaturated fatty acids in fat-1 mice ameliorate high-fat diet-induced non-alcoholic fatty liver disease. Biochem. Pharmacol. 84, 1359-1365.

Knekt P, Reunanen A, Jarvinen R, Seppanen R, Heliovaara M, Aromaa A. 1994. Antioxidant vitamin intake and coronary mortality in a longitudinal population study. Am. $J$. Epidemiol. 139, 1180-1189.

Kushi LH, Folsom AR, Prineas RJ, Mink PJ, Wu Y, Bostick RM. 1996. Dietary antioxidant vitamins and death from coronary heart disease in postmenopausal women. N. Engl. J. Med. 330, 1029-1035.

Kumada M, Kihara S, Sumitsuji S, Kawamoto T, Matsumoto S, Ouchi N, Arita Y, Okamoto Y, Shimomura I, Hiraoka H, Nakamura T, Fu-nahashi T, Matsuzawa Y. 2003. Association of hypoadiponectinemia with coronary artery disease in men. Arterioscler Thromb. Vasc. Biol. 23, 85-89.

Law MR, Wald NJ, Rudnicka AR. 2003. Quantifying effect of statins on low density lipoprotein cholesterol, ischaemic heart disease, and stroke: systematic review and metaanalysis. BMJ 326, 1423-1429.

Lim SS, Vos T, Flaxman AD, Danaei G, Shibuya K, AdairRohani $\mathrm{H}$ et al. 2012. A comparative risk assessment of burden of disease and injury attributable to 67 risk factors and risk factor clusters in 21 regions, 1990-2010: a systematic analysis for the Global Burden of Disease Study 2010. Lancet 380 (9859), 2224-2260.

Löliger J. 1991. The use of antioxidants in food. In: Free radicals and food additives. Aruoma OI, Halliwell B. Eds. Taylor and Francis, London, pp. 129-138.

Makni, M, Fetoui, H, Gargouri, NK, Garoui, EM, Jaber, H, Makni, J, Boudawara, T, Zeghal, N. 2008. Hypolipidemic and hepatoprotective effects of flax and pumpkin seed mixture rich in x-3 and x-6 fatty acids in hypercholesterolemic rats. Food and Chemical Toxicology 46, 3714-3720.

Matus Z, Molnár P, Szabó LG, Acta Pharm Hung. 1993. [Main carotenoids in pressed seeds (Cucurbitae semen) of oil pumpkin (Cucurbita pepo convar. pepo var. styriaca)] $63(5), 247-256$

Megraw R, Dunn D, Biggs H. 1979. Manual and continuous flow colorimetry of triglycerols by a fully enzymatic method. Clin. Chem. 25, 273-284.
Melendez-Martinez AJ, Vicario IM, Heredia FJ. 2004. Nutritional importance of carotenoid pigments. Arch. Latinoam. Nutr. 54, 149-154.

Mohamed DA.,Hamed TE, Al-Okbi SY. 2010. Reduction in hypercholesterolemia and risk of cardiovascular diseases by mixtures of plant food extracts:a study on plasma lipid profile, oxidative stress and testosterone in rats. Grasas $Y$ Aceites. 61, 378-389.

Mruk JS, Webster MW, Heras M, Reid JM, Grill DE, Chesebro JH. 2000. Flavone-8-acetic acid (Flavonoid) profoundly reduces platelet-dependent thrombosis and vasoconstriction after deep arterial injury. In vivo. Circulation 101, 324-328.

Morel DW, Chisolm GM. 1989. Antioxidant treatment of diabetic rats inhibits lipoprotein oxidation and cytotoxicity. J Lipid Res. 30, 1827-1834.

Murkovic M, Hillebrand A, Winkler J, Leitner E, Pfannhause W. 1996a. Variability of fatty acid content in pumpkin seeds (Cucurbita pepo L.). Z Lebensm Unters Forsch. 203 (3), 216-219.

Murkovic M, Hillebrand A, Winkler J, Pfannhauser W. 1996b. Variability of vitamin E content in pumpkin seeds (Cucurbita pepo L.). Z Lebensm Unters Forsch. 202 (4), 275-278.

Ouchi N, Ohishi M, Kihara S, Funahashi T, Nakamura T, Nagaretani H, Kumada M, Ohashi K, Okamoto Y, Nishizawa H, Kishida K, Maeda N, Nagasawa A, Kobayashi H, Hiraoka H, Komai N, Kaibe M, Rakugi H, Ogihara T, Matsuzawa Y. 2003. Association of hypoadiponectinemia with impaired vasoreactivity. Hypertension. 42, 231-234

Ouchi N, Shibata R, Walsh K. 2006. Cardioprotection by adiponectin. Trends Cardiovasc Med. 16, 141-146.

Prakash D, Gupta KR. 2009. Antioxidant phytochemicals of Nutraceutical Importance. The Open Nutraceuticals J. 2, $20-35$.

Phillips K, Ruggio D, Ashraf-Khorassani M. 2005. Phytosterol composition of nuts and seeds commonly consumed in the United States. J. Agric. Food Chem. 53, 9436-9445.

Pischon T, Girman CJ, Hotamisligil GS, Rifai N, Hu FB, Rimm EB. 2004. Plasma adiponectin levels and risk of myocardial infarction in men. JAMA 291, 1730-1737.

Rich MW. 2006. Heart failure in older adults. Med. North Am. 90 (5), 863-885, xi.

Risti-Medi D, Risti G, Tepsi V. 2003. Alpha-linolenic acid and cardiovascular diseases. Med. Pregl. 56 (Suppl 1), 19-25.

Ryan AS, Berman DM, Nicklas BJ, Sinha M, Gingerich RL, Meneilly GS, Egan JM, Elahi D. 2003. Plasma adiponectin and leptin levels, body composition, and glucose utilization in adult women with wide ranges of age and obesity. Diabetes Care, 26, 2383-2388.

Ryan E, Galvin K, O'Connor TP, Maguire AR, O'Brien NM. 2007. Phytosterol, squalene, tocopherol content and fatty acid profile of selected seeds, grains, and legumes. Plant Foods Hum Nutr. 62, 85-91.

Saad F, Gooren L. 2009. The role of testosterone in the metabolic syndrome: a review. J. Steroid Biochem. Mol. Biol. 114, $40-43$.

Saldeen K, Saldeen T. 2005. Importance of tocopherols beyond $\alpha$-tocopherol: evidence from animal and human studies. Nutr. Res. 25, 877-889.

Satoh K. 1978. Serum lipid peroxide in cerebrovascular disorders determined by a new colorimetric method. Clinica Chimica Acta. 90, 37-43.

Schiebel-Schlosser G, Friederich M. 1998. Phytotherapy of BPH with pumpkin seeds - a multicentric clinical trial. Z. Phytother. 19, 71-76.

Shimabukuro M, Higa N, Asahi T, Oshiro Y, Takasu N, Tagawa T, Ueda S, Shimomura I, Funahashi T, Matsuzawa Y. 2003. Hypoadiponectinemia is closely linked to endothelial dysfunction in man. J. Clin. Endocrinol Metab. 88, 3236-3240.

Stevenson DG, Eller FJ, Wang L, Jane JL, Wang T, Inglett GE. 2007. Oil and tocopherol content and composition of pumpkin seed oil in 12 cultivars. J. Agric. Food Chem. 55 (10), 4005-4013. 
Stewart-Lee AL, Ferns GA, Anggard EE. 1995. Differences in onset of impaired endothelial responses and in effects of vitamin $\mathrm{E}$ in the hypercholesterolemic rabbits carotid and renal arteries. J. Card Pharmacol. 25, 906-913.

Tan KC, Xu A, Chow WS, Lam MC, Ai VH, Tam SC, Lam KS. 2004. Hypoadiponectinemia is associated with impaired endothelium-dependent vasodilation. J. Clin. Endocrinol. Metab. 89, 765-769.

Thorand B, Baumert J, Chambless L, Meisinger C, Kobb H, Doring A. 2006. For the MONICA/KORA study group. Elevated markers of endothelial dysfunction predict type 2 diabetes mellitus in middle-aged men and women from the general population. Arterioscler Thromb. Vasc. Biol. 26, 398-405.

Tsimikas S, Philis-Tsimikas A, Alexopoulos S, Sigari F, Lee C, Reaven PD. 1999. LDL isolated from Greek subjects on a typical diet or from American subjects on an oleatesupplemented diet induces less monocyte chemotaxis and adhesion when exposed to oxidative stress. Arterioscler Thromb Vasc. Biol. 19, 122-130.

Van Hoed V, Felkner B, Bavec F, Grobelnik S, Bavec M, Verhe R. 2009. Influence of processing on antioxidants content of pumpkin seed oil. $7^{\text {th }}$ EuroFed Lipid Congress" Lipids, fats and oils" from knowledge to application, 18-21 October, Graz, Austria.

Vanstone CA, Raeini-Sarjaz M, Parsons WE, Jones PJ. 2002. Unesterified plant sterols and stanols lower LDL-cholesterol concentrations equivalently in hypercholesterolemic persons. Am. J. Clin. Nutr. 76, 1272-1278.

Watson D. 1960. A simple method for the determination of serum cholesterol. Clin. Chem. Acta. 5, 637-642.

Wenzel, C. 1987. Ernahrung/Nutrition 11, 752-755.

Yamauchi R. 2007. Addition products of alpha-tocopherol with lipid-derived free radicals. Vitam Horm 76, 309-327.

Yang R, Le G, Li A, Zheng J, Shi Y. 2006. Effect of antioxidant capacity on blood lipid metabolism and lipoprotein lipase capacity of rats feed a high-fat diet. Nutr. 22, $1185-1191$

Younis YM, Ghirmay S, al-Shihry SS. 2000. African Cucurbita pepo L.: properties of seed and variability in fatty acid composition of seed oil. Phytochemistry 54, 71-75.

Zambo I. 1988. Analytical standardization of peponen. Mediflora. 89, 6.

Ziv E, Patlas N, Kalman R, Pelled D, Herzog Y, Dror T, Cohen T. 2009. A high oleic sunflower oil fatty acid esters of plant sterols mixed with dietary diacylglycerol reduces plasma insulin and body fat accumulation in Psammomys obesus. Lipids Health Dis. 12, 42.

Zollner N, Kirsch K. 1962. Colorimetric method for determination of total lipids. Z. Ges. Exp. Med. 135, 545-550.

Zuhair HA, Abd El-Fattah AA, El-Sayed MI. 2000. Pumpkinseed oil modulates the effect of felodipine and captopril in spontaneously hypertensive rats. Pharmacol Res. 41, 555-563. 